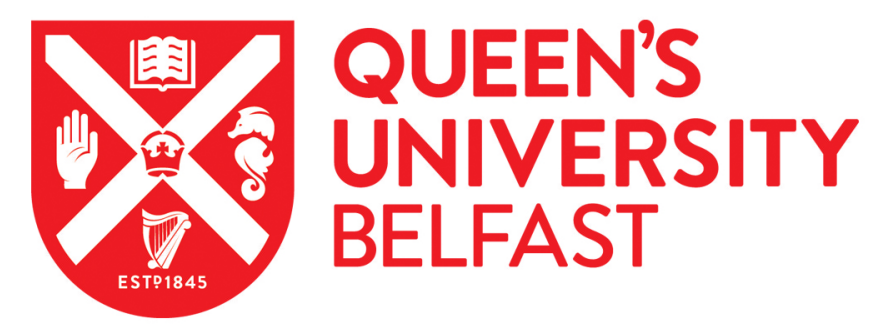

\title{
Optimizing acido-basic profile of support in Ni supported La2O3+Al2O3 catalyst for dry reforming of methane
}

\begin{abstract}
S.Al-Mubaddel, F., Kumar, R., Lanre Sofiu, M., Frusteri, F., Aidid Ibrahim, A., Kumar Srivastava, V., Olajide Kasim, S., Hamza Fakeeha, A., Elhag Abasaeed, A., Osman, A. I., \& Sadeq Al-Fatesh, A. (2021). Optimizing acido-basic profile of support in $\mathrm{Ni}$ supported $\mathrm{La2O} 3+\mathrm{Al} 2 \mathrm{O} 3$ catalyst for dry reforming of methane. International Journal of Hydrogen Energy. https://doi.org/10.1016/j.ijhydene.2021.01.173
\end{abstract}

Published in:

International Journal of Hydrogen Energy

Document Version:

Peer reviewed version

Queen's University Belfast - Research Portal:

Link to publication record in Queen's University Belfast Research Portal

\section{Publisher rights}

Copyright 2021 Elsevier.

This manuscript is distributed under a Creative Commons Attribution-NonCommercial-NoDerivs License

(https://creativecommons.org/licenses/by-nc-nd/4.0/), which permits distribution and reproduction for non-commercial purposes, provided the author and source are cited.

\section{General rights}

Copyright for the publications made accessible via the Queen's University Belfast Research Portal is retained by the author(s) and / or other copyright owners and it is a condition of accessing these publications that users recognise and abide by the legal requirements associated with these rights.

Take down policy

The Research Portal is Queen's institutional repository that provides access to Queen's research output. Every effort has been made to ensure that content in the Research Portal does not infringe any person's rights, or applicable UK laws. If you discover content in the Research Portal that you believe breaches copyright or violates any law, please contact openaccess@qub.ac.uk. 


\section{Optimizing acido-basic profile of support in Ni supported $\mathrm{La}_{2} \mathrm{O}_{3}+\mathrm{Al}_{2} \mathrm{O}_{3}$}

\section{2 catalyst for Dry Reforming of Methane}

3 Fahad Al-Mubaddel ${ }^{1,2}$, Rawesh Kumar ${ }^{3}$, Mahmud Lanre Sofiu $^{1}$, Francesco Frusteri ${ }^{4}$, 4 Ahmed Aidid Ibrahim¹, Vijay Kumar Srivastava ${ }^{3}$, Samsudeen Olajide Kasim ${ }^{1}$, Anis 5 Hamza Fakeeha', Ahmed Elhag Abasaeed ${ }^{1}$, Ahmed I. Osman5, Ahmed Sadeq Al6 Fatesh $^{1 *}$

$7{ }^{1}$ Chemical Engineering Department, College of Engineering, King Saud University, P.O. Box 800, Riyadh 11421, 8 Saudi Arabia.

$9 \quad{ }^{2}$ King Abdullah City for Atomic \& Renewable Energy, Energy Research \& Innovation Center (ERIC) in 10 Riyadh, Riyadh 11451, Saudi Arabia.

113 Sankalchand Patel University, Visnagar, Gujarat, India, 384315

$12{ }^{4}$ CNR-ITAE, Istituto di Tecnologie Avanzate per Energia "Nicola Giordano", Via S. Lucia sopra Contesse 5, 13 98126, Messina, Italy

$14{ }^{5}$ School of Chemistry and Chemical Engineering, Queen's University Belfast, Belfast BT9 5AG, Northern Ireland, 15 UK.

* Corresponding author. E-mail addresses: aalfatesh@ksu.edu.sa (A.S. Al-Fatesh)

\section{Abstract}

The increasing alarm of global warming always draws interest in reactions like dry reforming of methane (DRM) where both global warming gases $\left(\mathrm{CO}_{2}\right.$ and $\left.\mathrm{CH}_{4}\right)$ are converted into valueadded chemical building blocks, such as syngas. Nickel catalyst active sites along with support acid-base profiles play a key role in DRM. Herein, $\mathrm{xLa}_{2} \mathrm{O}_{3}+(100-\mathrm{x}) \mathrm{Al}_{2} \mathrm{O}_{3}(\mathrm{x}=0,10,15,20 \%)$ supports are prepared and followed by $\mathrm{NiO}$ dispersion over the produced support by impregnation method. It was tested for DRM reaction and characterized with TGA, XRD, TEM, IR, Surface area and porosity measurement, $\mathrm{H}_{2}-\mathrm{TPR}, \mathrm{CO}_{2}-\mathrm{TPD}$ and $\mathrm{NH}_{3}-\mathrm{TPD}$ techniques. Upon increasing the basic lanthana proportion in the acidic alumina support, the crystallinity of alumina and acidity of total support decline. Up to $15 \%$ Lanthana addition in support claims a low acid and rich basic surface including super basic sites (related to unidentate carbonates) which governed optimum catalytic performance $64 \% \mathrm{CH}_{4}$ conversion, $79 \% \mathrm{CO}_{2}$ conversion and $\mathrm{H}_{2} / \mathrm{CO} \sim 1$ up to 460 -minute in time on stream test. $20 \%$ lanthanum oxide loading led to inferior performance due to rapid loss of surface area, pore-volume, pore diameter, acidity and 
medium basic strength sites. Fine-tuning of acid-base lanthana-alumina support with dispersed Ni species are a means for understanding DRM.

Keywords: Acid-basic property, DRM, Super basic sites, Lanthana-Alumina

\section{Introduction}

Dry reforming of methane (DRM) always draws global attention due to converting two global warming causing gases, $\mathrm{CH}_{4}$ and $\mathrm{CO}_{2}$, into useful syngas, $\mathrm{CO}$ and $\mathrm{H}_{2}$, feedstock. It is a catalytic induced process generating syngas used as a viable fuel alternative to fossil fuel and a precursor for substantial chemicals such as methanol, ammonia, and synthetic hydrocarbon fuel production [1]. The application of inexpensive and readily available DRM catalysts with performance to outstandingly yield syngas has been the focal point of research and development in modern times. Versatile cheap catalysts for DRM are of utmost demand from the industry as well as environmental community. The Ni-based catalytic system is most trusted after noble metals Pt, Ru and Rh for DRM [2, 3, 4, 5, 6, 7]. Due to cheap and wide availability, $\mathrm{Ni}$ is investigated deeply for DRM by the research community. Dissociation of $\mathrm{CH}_{4}$ over the Ni surface into carbon deposits and $\mathrm{H}_{2}$ (irreversible dehydrogenation reaction) and thereafter oxidation of carbon deposit by $\mathrm{CO}_{2}$ into $\mathrm{CO}$ (reversible Boudouard reaction) of DRM is widely accepted (Equation (1) \& (2)) [8]. At high temperature, the Boudouard reaction shifts towards $\mathrm{CO}$ disproportionation, which is likely to decrease $\mathrm{CO}$ yield and decrease $\mathrm{CO}_{2}$ conversion and enhance carbon deposition.

$\mathrm{CH}_{4} \rightarrow \mathrm{C}+2 \mathrm{H}_{2}$

$\Delta \mathrm{H}=74.9 \mathrm{~kJ} / \mathrm{mol}$ 
Overall, $\mathrm{CH}_{4}+\mathrm{CO}_{2} \rightarrow 2 \mathrm{CO}+2 \mathrm{H}_{2} \quad \Delta \mathrm{H}=247 \mathrm{~kJ} / \mathrm{mol}$

However, overall $\mathrm{CH}_{4}$ conversion, $\mathrm{CO}_{2}$ conversion and $\mathrm{H}_{2} / \mathrm{CO}$ ratio are altered by other parallel reaction over the catalyst surface: (1) Reaction of product $\mathrm{H}_{2}$ with substrate $\mathrm{CO}_{2}$ gives $\mathrm{CO}$ and $\mathrm{H}_{2} \mathrm{O}\left(\mathrm{CO}_{2}+\mathrm{H}_{2} \rightarrow \mathrm{CO}+\mathrm{H}_{2} \mathrm{O}\right)$. This reaction is popularly known as reverse water gas shift reaction (RWGS), which causes a remarkable decrease in $\mathrm{H}_{2}$ yield, increase in $\mathrm{CO}$ yield and increase of $\mathrm{CO}_{2}$ conversion. (2) Gasification of carbon deposit by hydrogen gas into $\mathrm{CH}_{4}(\mathrm{C}+$ $2 \mathrm{H}_{2} \rightarrow \mathrm{CH}_{4}$ ) causes a decrease in $\mathrm{H}_{2}$ yield and a decrease of $\mathrm{CH}_{4}$ conversion [9]. (3) Gasification of carbon deposit by $\mathrm{H}_{2} \mathrm{O}$ into $\mathrm{CO}$ and $\mathrm{H}_{2}\left(\mathrm{C}+\mathrm{H}_{2} \mathrm{O} \rightarrow \mathrm{CO}+\mathrm{H}_{2}\right)$ causes an increase of $\mathrm{H}_{2}$ yield and $\mathrm{CO}$ yield.

Various attempts were reported to disperse the $\mathrm{Ni}$ on proper support with synthetic methodologies and conditions such that the maximum and stable catalytic conversion could be achieved. As DRM reaction is highly endothermic and catalyst supports like $\mathrm{SiO}_{2}, \mathrm{Al}_{2} \mathrm{O}_{3}$ and $\mathrm{ZrO}_{2}$ can sustain a high reaction temperature and hold the dispersed nickel species even at the high reaction temperatures. Among all supports, $\mathrm{Al}_{2} \mathrm{O}_{3}$ support is the cheapest and handy for industrial applications. Among the $\gamma-\mathrm{Al}_{2} \mathrm{O}_{3}$ and $\beta-\mathrm{Al}_{2} \mathrm{O}_{3}$ support, $\gamma-\mathrm{Al}_{2} \mathrm{O}_{3}$ supported $\mathrm{Ni}$ catalyst was found more suitable for DRM reaction as it holds large numbers of $\mathrm{C}_{\alpha}$ species (completely dehydrogenated carbides carbon) over its surface which resulted into higher $\mathrm{CO}_{2}$ conversion [10]. Presence of $\mathrm{NiAl}_{2} \mathrm{O}_{4}$ phases in the $\mathrm{Al}_{2} \mathrm{O}_{3}$ supported $\mathrm{Ni}$ catalyst system showed strong metal-support interaction, presenting high resistance against sintering and coking $[11,12]$. $\mathrm{Al}_{2} \mathrm{O}_{3}$ nanosheet support provides superior anchoring surface (100) for Ni nanoparticle where $\mathrm{Al}_{2} \mathrm{O}_{3}$ nanofiber support provides abundant confined space for steady chemisorption behaviour [13]. So, the earlier catalyst showed high catalytic conversion (> 85\% $\mathrm{CO}_{2}$ and $\mathrm{CH}_{4}$ conversion) with excellent $\mathrm{H}_{2}$ and $\mathrm{CO}$ selectivity whereas later catalyst system showed superior catalytic stability. Xiuzhong Fang et al.; has applied evaporation-induced self-assembly methodology (EISA) to prepare $\mathrm{Al}_{2} \mathrm{O}_{3}$ supported nickel-based catalyst [14]. The catalyst prepared by the 
EISA method had more dispersed, small and uniform Ni particle over-ordered mesopores support. This methodology claimed remarkable activity and potent coke resistance than that of the conventional impregnated catalyst. R.L.B.A. Medeiros et al.; had applied microwaveassisted combustion method (MAC) using urea [15]. The catalyst prepared by low urea content (2g) showed a high degree of reduction and high specific surface area of $266 \mathrm{~m}^{2} / \mathrm{g}$ which promoted better activity and 33\% lower deactivation levels. Yu Zhao et al.; prepared sandwiched catalyst $\mathrm{Al}_{2} \mathrm{O}_{3} / \mathrm{Ni} / \mathrm{Al}_{2} \mathrm{O}_{3}$ by atomic layer deposition of porous $\mathrm{Al}_{2} \mathrm{O}_{3}$ thin-film over $\mathrm{Ni} / \mathrm{Al}_{2} \mathrm{O}_{3}[16]$. Sandwich model of catalyst prevented $\mathrm{Ni}$ gathering as well as facilitates double interaction of $\mathrm{Ni}$ with $\mathrm{Al}_{2} \mathrm{O}_{3}$. Despite preparation complexity, this catalyst system had attained nearly $100 \% \mathrm{CO}_{2}$ and $\mathrm{CH}_{4}$ conversion with absolute selectivity towards $\mathrm{CO}$ and $\mathrm{H}_{2}$.

Apart from these, $\mathrm{Al}_{2} \mathrm{O}_{3}$ support also tunes acid-basic profile and reducibility of promoted/modified catalytic surface. Promotional addition of various basic $(\mathrm{Mg}, \mathrm{Sr})[17,18]$, acidic (B)[19], transition metal (Mn, Co, W)[20,21, 22] and redox (Ce, Zr, La)[23,24, 25] promotors had shown a remarkable effect on activity and coke resistance. Basicity enhances $\mathrm{CO}_{2}$ absorption, whereas acidity encounters $\mathrm{CH}_{4}$ dissociation. Cobalt controls Ni's ensemble size, whereas Mn partially blocks large Ni particles to slow down the coke formation [20,21]. W formed catalytic important Ni-W alloy species which hindered the carbon deposition inside the lattice, and further tungsten carbide was supposed to carry out carbon gasification [22]. Among the redox set, ceria was found promising to facilitate accessible mobile oxygen in the lattice for accelerating surface oxidation reactions during DRM [23]. $\mathrm{ZrO}_{2}$ addition enhanced the dissociation of $\mathrm{CO}_{2}$ at $\mathrm{Ni}-\mathrm{ZrO}_{2}$ boundary, and its redox property gasified the coke afterwards [24]. Recently, Al-Fatesh et al.; used $\mathrm{BO}_{\mathrm{x}}, \mathrm{SiO}_{2}, \mathrm{TiO}_{2}, \mathrm{ZrO}_{2}, \mathrm{MoO}_{\mathrm{x}}$ and $\mathrm{WO}_{\mathrm{x}}$ promoted $\mathrm{Ni}$ supported $\mathrm{Al}_{2} \mathrm{O}_{3}$ catalyst for $\mathrm{DRM}$ reaction where $\mathrm{Si}$ and $\mathrm{W}$ promoted catalyst nourished "excellent $\mathrm{Ni}$ dispersion" as well as "strongly interacted $\mathrm{NiO}$ species with support (or $\mathrm{NiAl}_{2} \mathrm{O}_{4}$ species)". This catalyst system conquered $>64 \% \mathrm{CH}_{4}$ conversion, $>70 \% \mathrm{CO}_{2}$ 
conversion and $>0.90 \mathrm{~mol} \mathrm{H}_{2} / \mathrm{CO}$ ratio [26]. Fakeeha et al.; used $\mathrm{Ni}$ supported $\mathrm{Al}_{2} \mathrm{O}_{3}$ catalysts promoted by $\mathrm{CuO}, \mathrm{ZnO}, \mathrm{Ga}_{2} \mathrm{O}_{3}$ and $\mathrm{Gd}_{2} \mathrm{O}_{3}$ among which $\mathrm{Gd}_{2} \mathrm{O}_{3}$ promoted catalyst claimed $87 \% \mathrm{H}_{2}$ yield with $\mathrm{H}_{2} / \mathrm{CO} \sim 1$ through DRM reaction [27]. The role of lanthana as a thermal stabilizer of $\mathrm{Al}_{2} \mathrm{O}_{3}$ at very high temperature $\left(1000-1100^{\circ} \mathrm{C}\right)$ was found substantial [28]. However, at DRM reaction condition $\left(600-800^{\circ} \mathrm{C}\right)$, the following significant surface catalytic features were attained in favor of DRM after lanthana addition. (1) Increasing metal-support interaction (Ni--Al) or enhancing $\mathrm{Ni}$ dispersion [29, 30]. (2) Optimizing the size of nickel particles for DRM [31, 32]. (3) Enhancing the basic characteristics which may induce the $\mathrm{CO}_{2}$ adsorption for oxidation of carbon deposits $[33,34]$. Again, upon increasing $\mathrm{CO}_{2}$ concentration, Boudouard equilibrium may shift towards $\mathrm{CO}$ formation, resulting in carbon deposit removal. (4) Enhancing the redox potential of $\mathrm{La}_{2} \mathrm{O}_{3} / \mathrm{La}_{2} \mathrm{O}_{2} \mathrm{CO}_{3}$, which could also gasify the carbon species $[25,35,36,37]$. (5) Minimizing the $\mathrm{H}_{2}$ consumption by inhibiting the reverse water gas shift reaction (RWGS) [38, 39].

Moreover, for bearing such qualities over catalyst surface, lanthana is also needed to be dispersed in alumina vicinity. Herein, we utilized the $\mathrm{x} \% \mathrm{La}_{2} \mathrm{O}_{3}+(100-\mathrm{x}) \% \mathrm{Al}_{2} \mathrm{O}_{3}$ as support to weave a close network of lanthana with $\mathrm{Al}_{2} \mathrm{O}_{3}$. Furthermore, Ni was deposited over $\mathrm{x} \% \mathrm{La}_{2} \mathrm{O}_{3}$ $+(100-\mathrm{x}) \% \mathrm{Al}_{2} \mathrm{O}_{3}$ support by the wet impregnation method. This combination facilitated good $\mathrm{Ni}$ dispersion and $\mathrm{Ni}$-support interaction over "lanthana containing $\mathrm{Al}_{2} \mathrm{O}_{3}$ support". The catalyst was abbreviated as $5 \mathrm{NixLa}(100-\mathrm{x}) \mathrm{Al})(\mathrm{x}=0,10,15,20 \mathrm{wt} \%)$.

\section{Experimental}

2.1. Materials

$\mathrm{La}\left(\mathrm{NO}_{3}\right)_{3} .6 \mathrm{H}_{2} \mathrm{O}, \mathrm{Ni}\left(\mathrm{NO}_{3}\right)_{2} \cdot 6 \mathrm{H}_{2} \mathrm{O}$, deionized water, mesoporous $\gamma-\mathrm{Al}_{2} \mathrm{O}_{3}$, crucible, crusher (mortar with a pestle).

\subsection{Catalyst Preparation}


The weight of an empty crucible was measured and recorded. Depending on the catalyst's desired composition and mass, a calculated amount of the support (meso- $\gamma-\mathrm{Al}_{2} \mathrm{O}_{3}$ ) was weighed and poured into the empty crucible. Also, specific masses of $\mathrm{La}\left(\mathrm{NO}_{3}\right)_{3} \cdot 6 \mathrm{H}_{2} \mathrm{O}$ and $\mathrm{Ni}$ $\left(\mathrm{NO}_{3}\right)_{2} .6 \mathrm{H}_{2} \mathrm{O}$ were added to the crucible containing the support to obtain a powder mixture. The percentage weight of $\mathrm{Ni}$ in all of the synthesized catalysts was made at a fixed value of $5 \mathrm{wt} . \%$. The mixture was grounded thoroughly until all the greenish colour of nickel nitrate has disappeared. Deionized water was added dropwise to the ground powder mixture in the crucible to form a paste. It was well stirred, and the water was allowed to evaporate under ambient condition overnight. The crucible plus sample's weight was measured, and subsequently, that of the sample was determined after drying overnight. Thereafter, the dried sample was calcined at $700^{\circ} \mathrm{C}$ for 3 hours. The calcined $5 \mathrm{wt} \% \mathrm{Ni}-\mathrm{x}$ wt $\% \mathrm{La}_{2} \mathrm{O}_{3}-(100-\mathrm{x}) \mathrm{Al}_{2} \mathrm{O}_{3}(\mathrm{x}=0,10,15$, and 20 wt $\%$ ) catalysts were abbreviated as $5 \mathrm{NixLa}(100-\mathrm{x}) \mathrm{Al}$ where $\mathrm{x}=1,10,15$ and $20 \mathrm{wt} \%)$.

\subsection{Catalytic reaction}

The catalyst activity test is described in detail in the supporting information S1.

\subsection{Catalyst characterization}

The specification and analysis details are described in the supporting information S2.

\section{Result}

3.1. Catalytic activity and thermal gravimetric analysis results

The catalytic activity of $5 \mathrm{NixLa}(100-\mathrm{x}) \mathrm{Al}(\mathrm{x}=0,10,15,20 \mathrm{wt} \%)$ catalytic system is shown in Fig. 1(A) -1(C). The $5 \mathrm{Ni} 100 \mathrm{Al}$ catalyst showed $55-51 \% \mathrm{CH}_{4}$ conversion and $69-66 \% \mathrm{CO}_{2}$ conversion, $\mathrm{H}_{2} / \mathrm{CO} \sim 0.88$ to 0.85 up to 460 minutes in the time on stream test. $5 \% \mathrm{Ni}$ impregnated on dual support (10\% basic lanthana, and $90 \%$ acidic alumina) and was denoted as $5 \mathrm{Ni10La90Al}$. It showed constant $\sim 57 \% \mathrm{CH}_{4}$ conversion and constant $\sim 73 \% \mathrm{CO}_{2}$ conversion and $\mathrm{H}_{2} / \mathrm{CO} \sim 0.93-0.89$ up to 460 minutes in time on stream test. 5Ni15La85Al catalyst showed optimum catalytic activity of $64 \% \mathrm{CH}_{4}$ conversion and $79 \% \mathrm{CO}_{2}$ conversion 
with $\mathrm{H}_{2} / \mathrm{CO} \sim 1$ up to 460 -minute in the time on stream test. Lanthana loading of 20 wt.\%

$154(5 \mathrm{Ni} 20 \mathrm{La} 80 \mathrm{Al})$ showed $\sim 55 \% \mathrm{CH}_{4}$ conversion and $\sim 70 \mathrm{CO}_{2}$ conversion, $\mathrm{H}_{2} / \mathrm{CO} \sim 0.87-0.82$.

155 The catalytic performance of $5 \mathrm{Ni} 20 \mathrm{La} 80 \mathrm{Al}$ was almost similar to the catalyst's performance

156 without lanthana loading (5Ni100Al).

157 Thermal gravimetric analysis (TGA) result of spent $5 \mathrm{NixLa}(100-\mathrm{x}) \mathrm{Al}(\mathrm{x}=0,10,15,20 \mathrm{wt} \%)$

158 catalyst samples is shown in Fig. S1. Spent 5Ni100Al catalyst showed continuous weight loss

159 up to $830^{\circ} \mathrm{C} .3 \%$ weight loss in the initial 10 minutes $\left(<200^{\circ} \mathrm{C}\right)$ due to loss of moisture from

160 the surface, $7 \%$ weight loss in next $10-35$ minutes $\left(<600{ }^{\circ} \mathrm{C}\right)$ due to loss of amorphous carbon

161 and $17 \%$ weight loss in the range of $35-50$ minute $\left(600-800{ }^{\circ} \mathrm{C}\right)$ is due to loss of graphitic

162 carbon [40]. The effect of Lanthana addition in support can be observed clearly. The major

163 weight loss region $600-800{ }^{\circ} \mathrm{C}$ (due to graphitic carbon) is completely absent in all Lanthana

164 containing catalyst. It may be expected that the basic property of Lanthana may improve $\mathrm{CO}_{2}$

165 absorption and thereby enhancing the reverse Boudouard reaction to eliminate carbon deposits

166 during the DRM reaction $[41,42]$.

167

168 


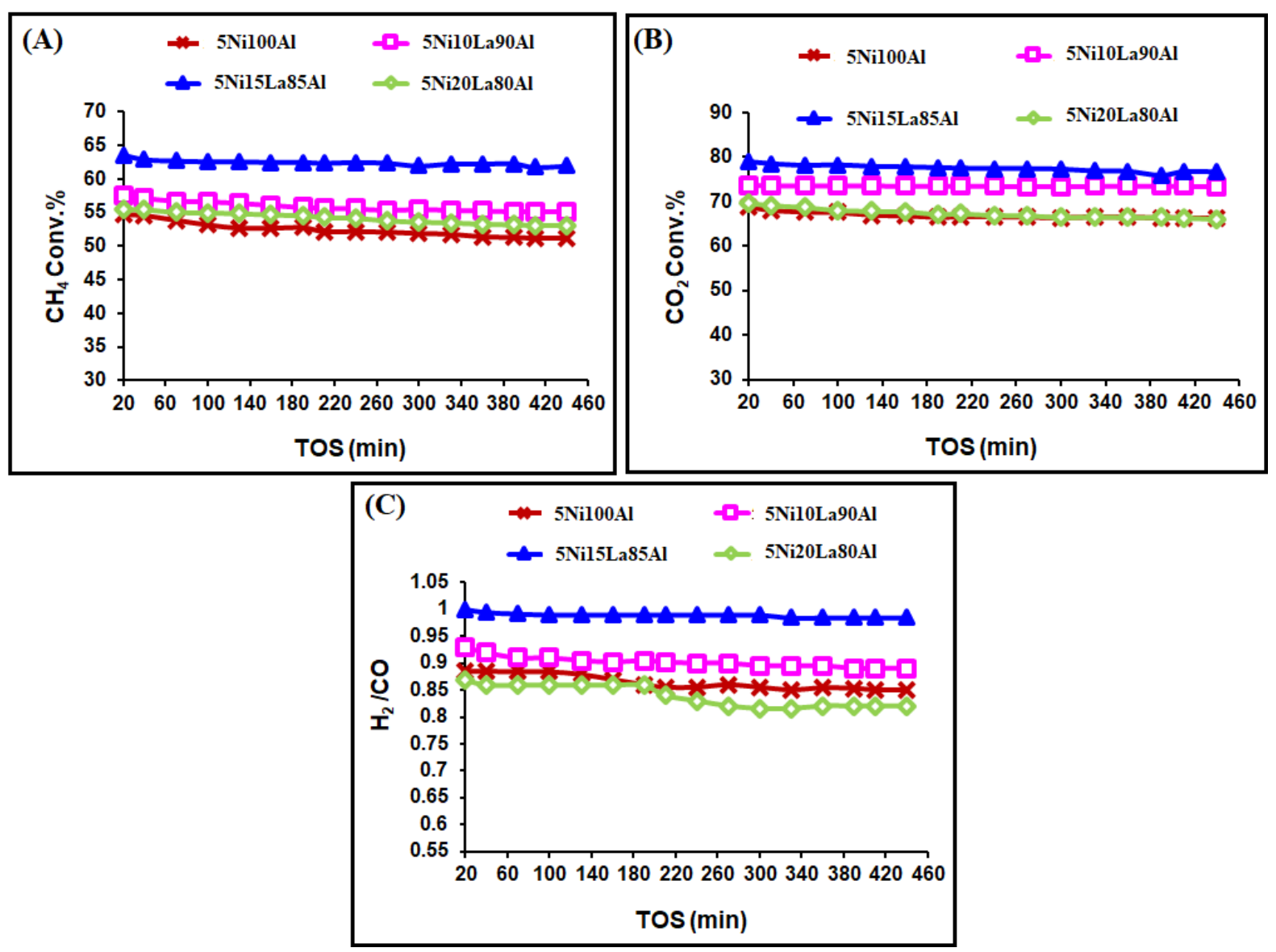

170 Fig. 1. Catalytic activity of $5 \mathrm{NixLa}(100-\mathrm{x}) \mathrm{Al}(\mathrm{x}=0,10,15,20 \mathrm{wt} \%)$ catalyst samples (A) $171 \mathrm{CH}_{4}$ conversion against time-on-stream (TOS), (B) $\mathrm{CO}_{2}$ conversion against TOS, and (C) $172 \mathrm{H}_{2} / \mathrm{CO}$ ratio against TOS

\subsection{Characterization Results}

3.2.1 X-ray diffraction: The XRD profiles of the different fresh and spent $5 \mathrm{NixLa}(100-\mathrm{x}) \mathrm{Al}(\mathrm{x}$ $=0,10,15,20 \mathrm{wt} \%)$ catalyst samples are shown in Fig. 2 (A-C). The 5Ni100Al catalyst showed diffraction lines that correspond to aluminium oxide (JCPDS card reference no. 00-001-1308, 01-080-1385) and nickel aluminium oxide crystalline (JCPDS card reference no. 00-001-1299) major peaks at $2 \theta=31.2^{\circ}, 37.17^{\circ}, 45.6^{\circ}, 66^{\circ}$ at plane (220), (311), (400), (440), respectively [43]. Nickel aluminium oxide's formation is generally reported on $\mathrm{Al}_{2} \mathrm{O}_{3}$ supported nickel system as it is a diffusion couple of $\mathrm{NiO}$ and $\mathrm{Al}_{2} \mathrm{O}_{3}$ [44]. It is interesting to observe that beyond the $15 \mathrm{wt} \%$ lanthana loading, the crystallinity of the catalyst is faded and becomes amorphous. That means the basic addition of lanthana oxide dignified the acidic crystalline structures of 

alumina, alumina's surface crystallinity decreases from crystalline to amorphous phase [45]. XRD profile of spent catalyst showed bulk crystalline carbon diffraction lines at $2 \theta=44.2^{\circ}$ (JCPDS card reference no. 01-075-0410) and metallic nickel at $2 \theta=44.3^{\circ}$ and $51.6^{\circ}$ (JCPDS card reference no. 00-001-1258), respectively in Fig. 2(B-C). The crystallinity of aluminium oxide and nickel aluminium oxide was impacted during the DRM reaction as the intensity of $(4,4,0)$ at $2 \theta=66^{\circ}$ brag angle was reduced. However, after lanthana addition with alumina support, the crystallinity was retained after the DRM reaction.
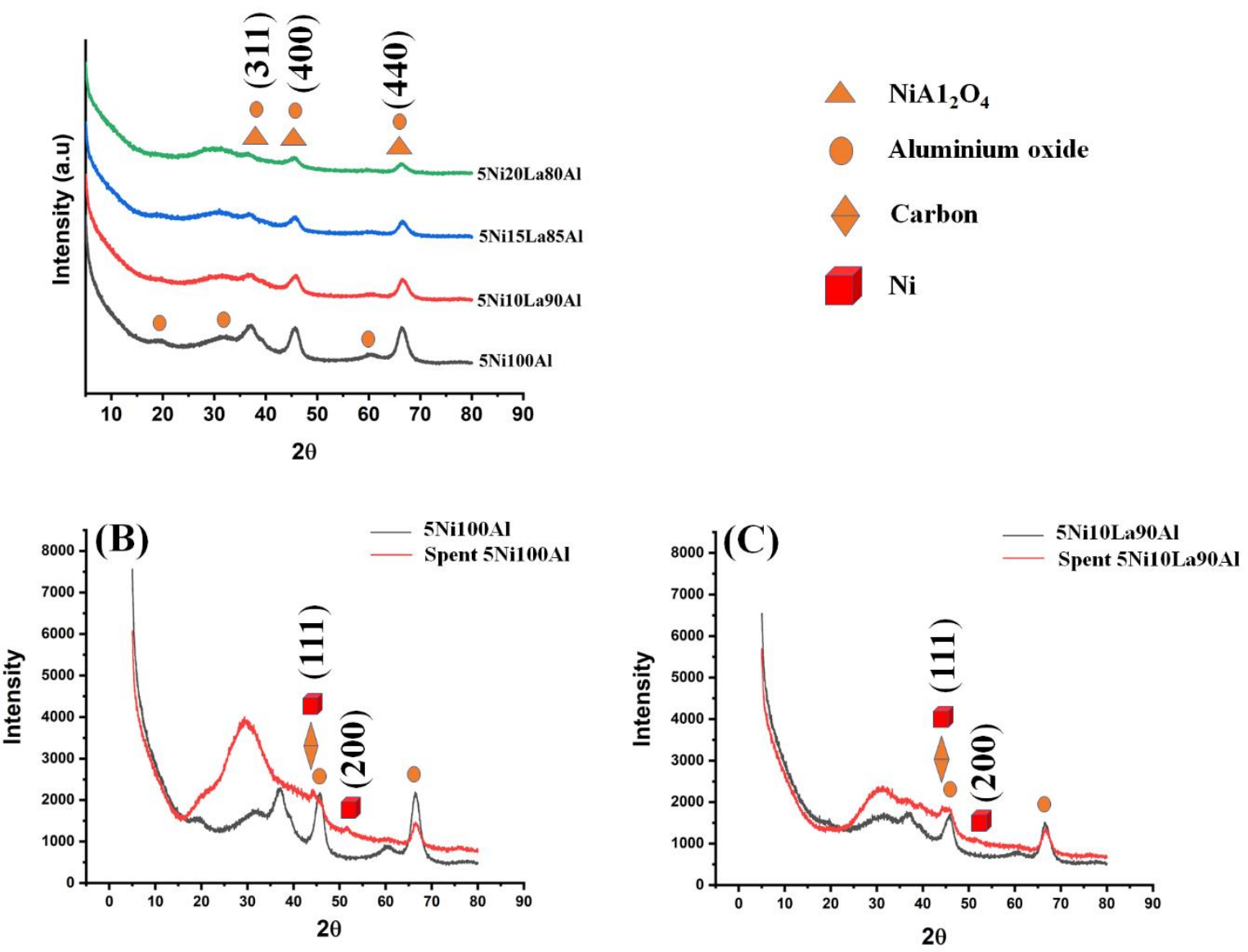

Fig. 2. The XRD profile of different fresh and spent $5 \mathrm{NixLa}(100-\mathrm{x}) \mathrm{Al}(\mathrm{x}=0,10,15,20 \mathrm{wt} \%)$ catalyst sample.

3.2.2. Transmission Electron Microscopy (TEM): The TEM images of fresh and spent 5 NixLa $(100-\mathrm{x}) \mathrm{Al}(\mathrm{x}=0,10,15,20 \mathrm{wt} \%)$ catalyst samples are shown in Fig. 3. TEM image also 

species of an average size of $6.2 \mathrm{~nm}$. In the TEM image of spent 5Ni20La80Al and 5Ni15La85Al catalyst system, the carbon nanotubes can be easily observed, which resulted from carbon deposition over the catalyst.
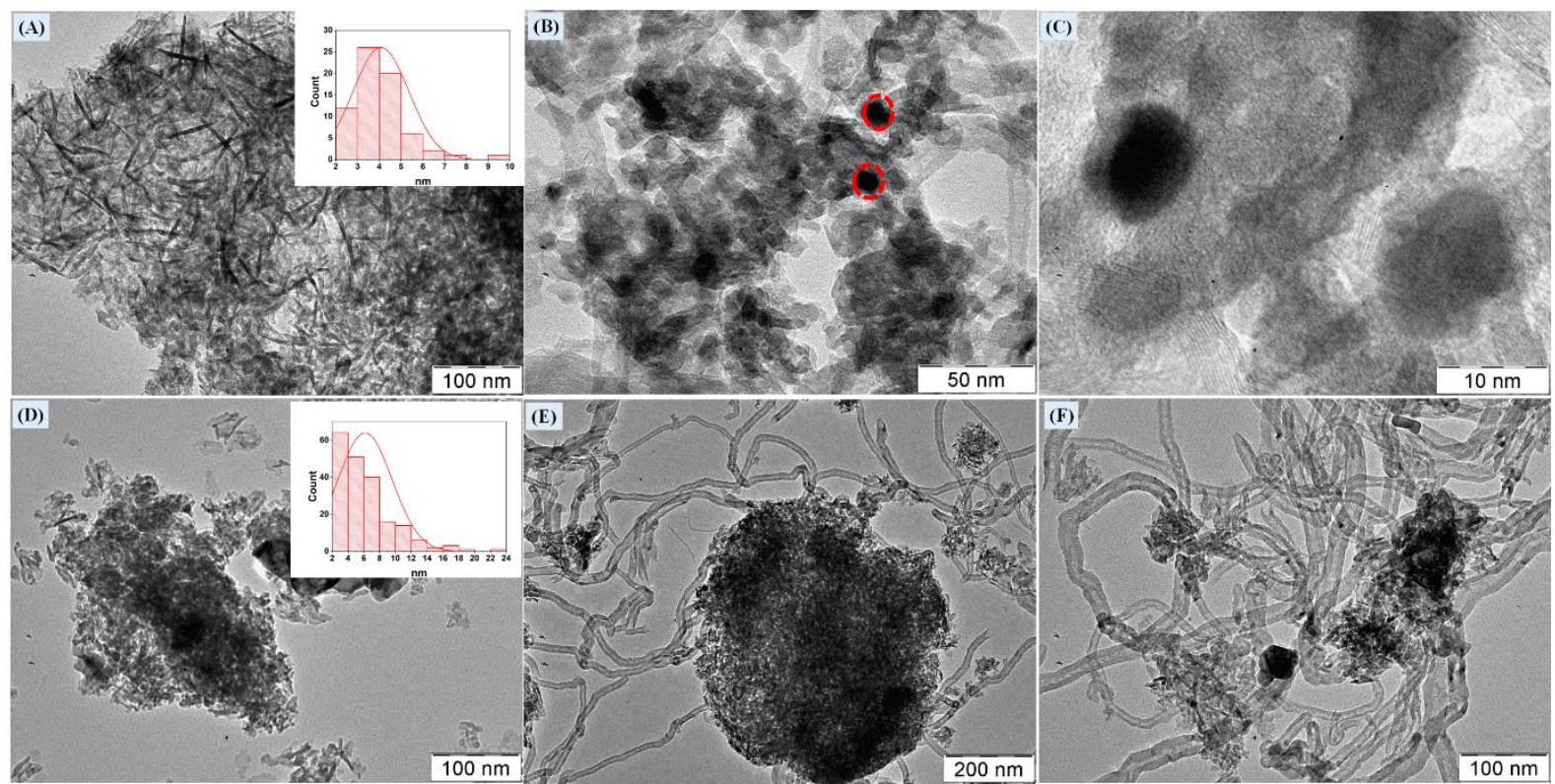

Fig. 3. TEM image of (A) 5Ni15La85Al catalyst; inset figure shows distribution curve of Ni species (B)-(C) spent $5 \mathrm{Ni} 15 \mathrm{La} 85 \mathrm{Al}$ catalyst (D) 5Ni20La80Al catalyst; inset figure shows distribution curve of $\mathrm{Ni}$ species (E)-(F) spent 5Ni20La80Al catalyst catalytic sample systems are shown in Fig. 4 (A). $\gamma-\mathrm{Al}_{2} \mathrm{O}_{3}$ is characterized by the presence of all three absorption bands at 1635,1517 and $1382 \mathrm{~cm}^{-1}[46,47]$. The absorption band at 2349 $\mathrm{cm}^{-1}$ is attributed to physically adsorbed $\mathrm{CO}_{2}$ gases [48]. The absorption bands at 1730 and $1270 \mathrm{~cm}^{-1}$ indicated bidentate $\mathrm{CO}_{2}$ chemisorbed species over $\gamma$-alumina [49]. After $10 \%$

217 lanthana addition with alumina dual supports, 1730 and $1270 \mathrm{~cm}^{-1}$ absorption bands 218 disappeared, and an absorption band at $1517 \mathrm{~cm}^{-1}$ increased in intensity. Basic $\mathrm{La}_{2} \mathrm{O}_{3}$ would 
interact with acidic $\mathrm{CO}_{2}$ and may form unidentate carbonate. It indicates partial diffusion of $\mathrm{La}^{+3}$ into $\mathrm{Al}^{+3}$, and the infrared band for "unidentate carbonate species coordinated to La" showed impression on band especially around $1517-1530 \mathrm{~cm}^{-1}[50,51,52]$. Further lanthana addition at $15 \mathrm{wt} . \%$ in $5 \mathrm{Ni} 15 \mathrm{La} 85 \mathrm{Al}$ catalyst showed absorption bands for both unidentate as well as bidentate carbonate species. However, when infra-red spectra of " $\mathrm{CO}_{2}$-TPD treated 5Ni15La85Al" catalyst system was taken, the absorption bands that are attributed to a hydroxyl group (at 1635 and $3460 \mathrm{~cm}^{-1}$ ) decreased in intensity and absorption bands attributed to bidentate carbonate species (at 1730 and $1270 \mathrm{~cm}^{-1}$ ) are completely absent (Fig. 4 B) [53]. The absorption bands correspond to unidentate species at $1517 \mathrm{~cm}^{-1}$ also got reduced. It indicates that at high temperature, surface hydroxyl species are reduced, and so $\mathrm{CO}_{2}$ interactions on hydroxylated oxide surfaces were decreased such that $\mathrm{CO}_{2}$ bidentate species were lost completely whereas unidentate species remained on the catalyst surface $[54,55]$. Thus, under catalyst surface. The absorption bands attributed to ionic anhydrous lanthanum carbonate at 1464, 1084 and $859 \mathrm{~cm}^{-1}$ were completely absent in these catalytic systems [56].
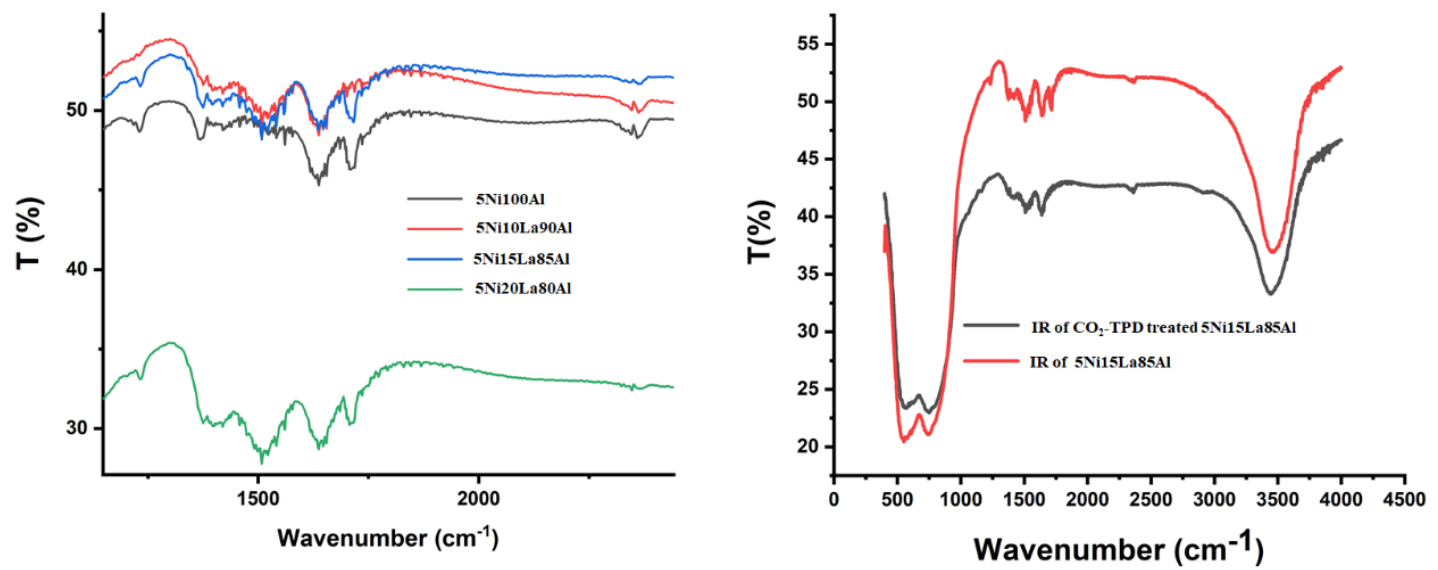

Fig. 4. Infra-red spectra of $5 \mathrm{NixLa}(100-\mathrm{x}) \mathrm{Al}(\mathrm{x}=0,10,15,20 \mathrm{wt} \%)$ catalyst samples 

$\mathrm{x}) \mathrm{Al}(\mathrm{x}=0,10,15,20 \mathrm{wt} \%)$ samples are plotted in Fig. 5, and the textural data are depicted in

Table 1. All samples indicated typical type IV adsorption/desorption isotherms with H1 hysteresis loop. Point of inflection at a relative pressure was in the range of $0.6-0.75$ corresponds to the capillary condensation, which indicated uniformity of the pores in mesoporous materials $[57,58]$. After loading 10wt.\% lanthana, the surface area, pore volume and pore diameter all decreased. It indicated a possible deposition of lanthanum oxide into the pores of the alumina support. On $15 \mathrm{wt}$. $\%$ lanthana loading, the surface morphology was not only retained but improved. In XRD also; at $15 \mathrm{wt} \%$ Lanthana loading, the crystallinity of catalyst is faded, which may improve the surface parameters [59]. It indicated that from 10$15 \mathrm{wt} . \%$ lanthana loading, lanthanum is successfully incorporated into the aluminium network and expanded the framework. Hence improved the surface morphology of the catalytic system; thus, this loading was found optimum. So, at $15 \%$ La loading, pore occlusion was decreased (than $10 \%$ La loading) due to the expansion of surface parameters. Further loading at $20 \mathrm{wt} . \%$ lanthana, all the three texture parameters were significantly decreased, indicating rapid deposit of lanthana in the pores and forming clusters and hence blocked the pore structure of the parent alumina support.
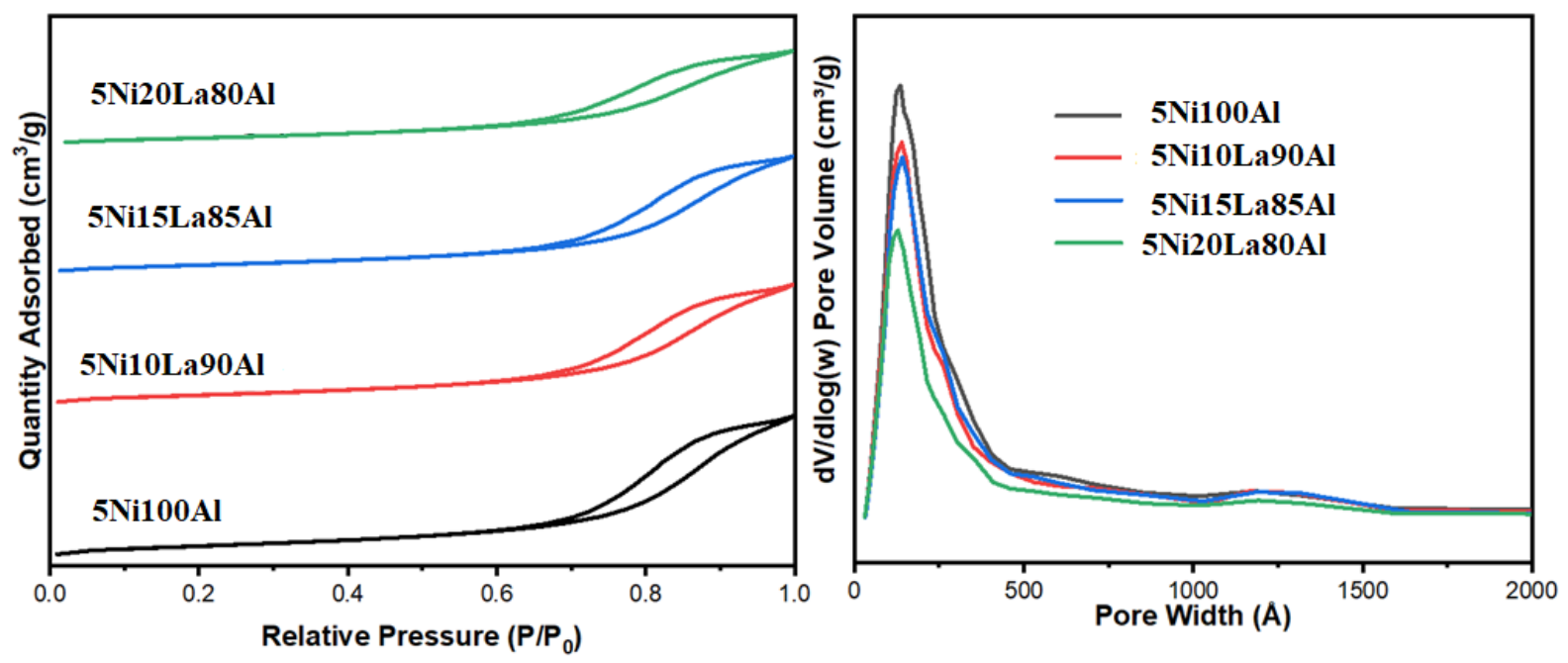
Fig. 5. $\mathrm{N}_{2}$ physisorption and $\mathrm{BJH}$ adsorption pore size distribution plots for $5 \mathrm{NixLa}(100-\mathrm{x}) \mathrm{Al}$ $(\mathrm{x}=0,10,15,20 \mathrm{wt} \%)$ catalyst samples

Table 1. Textural properties $\left(\mathrm{S}_{\mathrm{BET}}, \mathrm{P}_{\mathrm{v}}\right.$, and $\left.\mathrm{P}_{\mathrm{d}}\right)$ of $5 \mathrm{NixLa}(100-\mathrm{x}) \mathrm{Al}(\mathrm{x}=0,10,15,20 \mathrm{wt} \%)$ catalyst samples

\begin{tabular}{|c|c|c|c|}
\hline Catalyst & Sbet, $\mathrm{m}^{2} / \mathrm{g}$ & $P_{v}, \mathrm{~cm}^{3} / \mathrm{g}$ & $\mathbf{P}_{\mathrm{d}}, \mathbf{n m}$ \\
\hline 5Ni100Al & 185.6 & 0.64 & 12.4 \\
\hline 5Ni10La90Al & 161.7 & 0.55 & 12.2 \\
\hline $5 \mathrm{Ni} 15 \mathrm{La} 85 \mathrm{Al}$ & 162.2 & 0.61 & 12.9 \\
\hline 5Ni20La80Al & 134.9 & 0.49 & 12.2 \\
\hline
\end{tabular}

\subsection{5. $\mathrm{H}_{2}$-Temperature Programmed Reduction $\left(\mathrm{H}_{2}-\mathrm{TPR}\right)$}

$\mathrm{H}_{2}$-temperature-programmed reduction profiles of $5 \mathrm{NixLa}(100-\mathrm{x}) \mathrm{Al}(\mathrm{x}=0,10,15,20 \%)$ samples are shown in Fig. 6. All catalyst samples showed $\mathrm{H}_{2}$-TPR peaks after $600^{\circ} \mathrm{C}$. This indicates the strong interaction between the $\mathrm{Ni}$ species with the support as hence there was no free $\mathrm{NiO}$ reduction peak in the low-temperature region. The TPR peak at around $750-850^{\circ} \mathrm{C}$ can be attributed to the reduction of $\mathrm{NiAl}_{2} \mathrm{O}_{4}$ spinel, which might be ascribed to the strong interaction between $\mathrm{NiO}$ and $\mathrm{Al}_{2} \mathrm{O}_{3}[31,60,61,62]$. The effect of $\mathrm{La}$ addition to support can be seen clearly. In the 5Ni10La90Al catalyst sample, reduction peaks of nickel aluminate were decreased. For the 5Ni15La85Al catalyst sample, reduction peak shifted to the higher temperature region, which signified the strong interaction of $\mathrm{NiO}$ with support. $5 \mathrm{Ni} 20 \mathrm{La} 80 \mathrm{Al}$ catalyst showed reduction profile very similar to $5 \mathrm{Ni} 10 \mathrm{La} 90 \mathrm{Al}$ catalyst. 


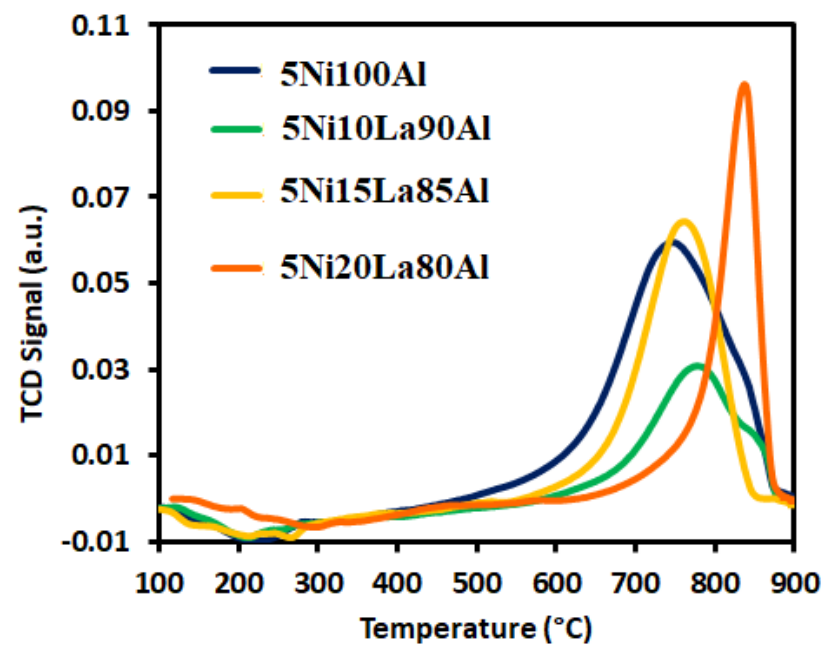

Fig. 6. The $\mathrm{H}_{2}$-TPR profiles of $5 \mathrm{NixLa}(100-\mathrm{x}) \mathrm{Al}(\mathrm{x}=0,10,15,20 \mathrm{wt} \%)$ catalyst system

\subsection{6. $\mathrm{CO}_{2}$-Temperature Programmed De-adsorption $\left(\mathrm{CO}_{2}-\mathrm{TPD}\right)$}

To understand the catalyst surface's basic profile, $\mathrm{CO}_{2}$-TPD has been carried out and shown in Fig. 7 (A). The desorption $\mathrm{CO}_{2}$ peaks qualitatively differentiated the catalyst surface into four types of basic regions [63]. The peak below $100^{\circ} \mathrm{C}$ indicated weak basic sites related to surface hydroxyl, below $200^{\circ} \mathrm{C}$ for intermediate strength -basic sites related to bidentate carbonates, peak $250^{\circ}-400{ }^{\circ} \mathrm{C}$ for strong basic sites associated with isolated $\mathrm{O}_{2}{ }^{-}$species and peak at a high temperature of super basic sites associated with unidentate carbonates $[64,65]$. All catalysts have a little amount of medium strength bidentate carbonate species. Interestingly, after the addition of $10 \%$ basic lanthana, basic sites regions decreased relative to 5Ni100Al. IR spectra also indicated the disappearance of bidentate carbonate species at $10 \%$ lanthana loading, affecting the density of the basic sites. After addition of $15 \mathrm{wt} . \%$ basic lanthana, the basic sites are greatly nurtured at the catalyst surface. This surface was enriched with a wide variety of basic sites as well as it also bears a broad peak of super basic sites. IR spectra also indicated the presence of unidentate as well as bidentate carbonate species at $15 \%$ lanthana loading. It may be a clear indication of the best activity of the 5Ni15La85Al amongst the rest of the catalysts. 
To understand the acid profile of the catalyst surface, $\mathrm{NH}_{3}-\mathrm{TPD}$ has been carried out and are shown in Fig. 7 (B). For catalyst 5Ni100Al, as the support is acidic, it had a wide range of acid sites over the catalyst surface. It was observed that with increasing La content on alumina supported Ni catalysts, the acid sites density decreased. It seems that the La addition to alumina played a crucial role in neutralizing the acidity of the alumina. Overall, the 5Ni15La85Al catalyst system can be characterized as the low acid profile catalyst system. Strong acidic catalyst system inhibits dissociative chemisorption of $\mathrm{CO}_{2}$ onto the catalyst surface. Proper $\mathrm{CO}_{2}$ dissociation and thereafter oxidation of carbon deposit can take place over low acidic catalyst system. So, the low acidic catalyst system is known for coke free DRM operation
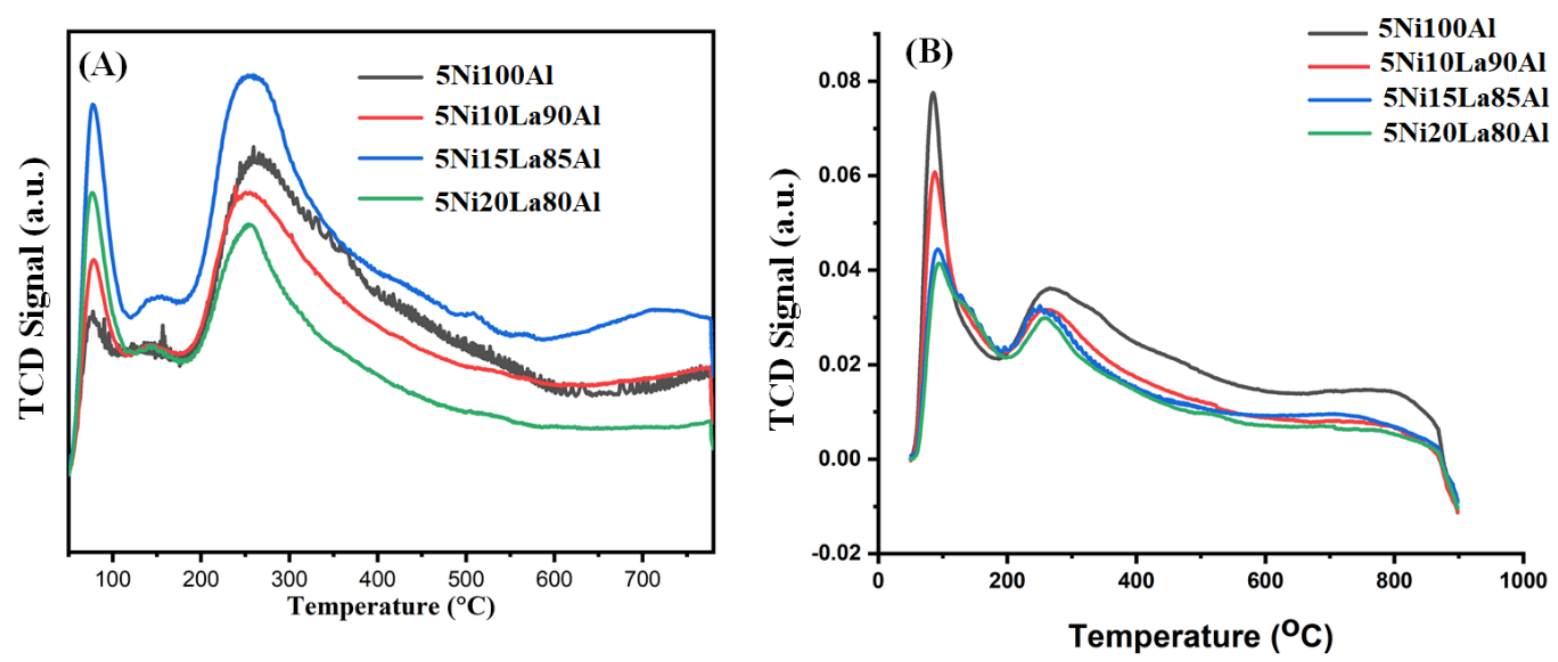

Fig. 7. Temperature Programmed Desorption profile of $5 \mathrm{NixLa}(100-\mathrm{x}) \mathrm{Al}(\mathrm{x}=0,10,15,20$ $\mathrm{wt} \%$ ) catalyst system (A) $\mathrm{CO}_{2}$-TPD (B) $\mathrm{NH}_{3}$-TPD.

\section{Discussion}

Absence of $\mathrm{NiO}$ diffraction crystalline peaks in all catalyst samples showed that alumina and lanthana-alumina are good crystalline dual-support to carry dispersed $\mathrm{Ni}$ species at high temperature. In all catalytic systems, $\mathrm{CO}_{2}$ conversion was higher than $\mathrm{CH}_{4}$ conversion which indicated that $\mathrm{CO}_{2}$ was also involved in other reaction such as RWGS reaction $\left(\mathrm{CO}_{2}+\mathrm{H}_{2} \rightarrow\right.$ $\mathrm{CO}+\mathrm{H}_{2} \mathrm{O}$ ) other than DRM [69]. Due to the RWGS reaction, $\mathrm{H}_{2}$ was consumed, and $\mathrm{CO}$ is 
released. So, $\mathrm{H}_{2} / \mathrm{CO}$ ratio may be affected seriously. Now over $5 \mathrm{Ni100Al}$, reducible nickel aluminate amount, expanded surface parameters and a moderate amount of weak as well as strong basic sites rendered good catalytic activity of $55 \% \mathrm{CH}_{4}$ conversion and $70 \% \mathrm{CO}_{2}$ conversion. Besides, the rich surface acid profile of 5Ni100Al competed for the methane decomposition with lower $\mathrm{H}_{2}$ yield and higher carbon accumulation [70]. So, it had the lowest $\mathrm{H}_{2} / \mathrm{CO}$ ratio of 0.88 and showed the highest carbon deposition $\left(17 \%\right.$ within $\left.550-750^{\circ} \mathrm{C}\right)$ over catalytic active sites, thus causing the catalyst deactivation.

Besides, the basic 10wt.\% lanthana joined the acidic alumina as a dual-support system. The crystallinity of alumina was lost (as observed in XRD), surface parameter (surface area, pore volume and pore diameter) declined, and acid sites density slowly depleted (as observed in $\mathrm{NH}_{3}$-TPD). Interestingly, bidentate carbonate species or basic sites are devastated (as observed in $\mathrm{CO}_{2}$-TPD), but unidentate carbonates are gathered at the catalyst surface (as observed in IR). Reducible nickel aluminate and vanishing acid sites (as observed in $\mathrm{NH}_{3}$-TPD) did not feed excess carbon deposits to the catalyst surface, and carbon deposits are regularly washed away by $\mathrm{CO}_{2}$ through the oxidation process. Overall, this catalyst rendered constant $\mathrm{CH}_{4}$ conversion $\sim 57 \%$ and constant $\mathrm{CO}_{2}$ conversion $\sim 73 \%$ up to 460 minutes in time on stream test with minimum carbon deposition. Lower acid site density of $5 \mathrm{Ni} 10 \mathrm{La} 90 \mathrm{Al}$ led to higher $\mathrm{H}_{2} / \mathrm{CO}$ ratio 0.93 relative to $5 \mathrm{Ni100 \textrm {Al }}$.

5Ni15La85Al had reducible "NiO supported species", a wide range of basic site density including super basic sites (related to unidentate carbonates) and a lower amount of acid site density. Low acid profile and rich basic profile facilitated control of $\mathrm{CH}_{4}$ dissociation and supported $\mathrm{CO}_{2}$ dissociative chemisorption onto catalyst surface to oxidate carbon deposits. The fine-tuning of acid and basic sites inhibited the pulverization and graphitization of carbon deposits responsible for the catalyst deactivation. Overall, it had an optimum catalytic activity 
of $64 \% \mathrm{CH}_{4}$ conversion and $79 \% \mathrm{CO}_{2}$ conversion with $\mathrm{H}_{2} / \mathrm{CO} \sim 1$ up to 460 -minute in the time on stream test.

341 Lanthana loading up to $20 \%$ with alumina supports claimed minimum crystallinity, most compact surface parameters (surface area, pore volume and pore diameter), minimum acidity, minimum strong basic site density and more carbon deposits after 5Ni100Al. However, it had a moderate amount of weak basic sites more than that of 5Ni100Al catalyst. Overall, $\mathrm{CH}_{4}$ conversion and $\mathrm{CO}_{2}$ conversion, $\mathrm{H}_{2} / \mathrm{CO}$ ratio and even carbon deposits from the TGA profiles of $5 \mathrm{Ni} 20 \mathrm{La} 80 \mathrm{Al}$ remained very similar to that of $5 \mathrm{Ni} 100 \mathrm{Al}$ catalyst.

\section{Conclusion}

$\mathrm{NiO}$ is well dispersed over alumina and lanthana-alumina dual-support. On increasing basic lanthana proportion in acidic alumina, the crystallinity of alumina and acidity of total support declined. 15wt.\% lanthana was the optimum loading in the lanthana-alumina dual-support system, at 5Ni15La85Al, a wide range of basic site densities, including super basic sites (related to unidentate carbonates) are nurtured additionally. A combat balance between the acid sites and basic sites over the catalyst surface controlled the $\mathrm{CH}_{4}$ decomposition, carbon deposit oxidation by $\mathrm{CO}_{2}$ and inhibition of the pulverization and carbon deposit graphitization.

Altogether, 5Ni15La85Al ensured low carbon deposit as well as the optimum catalytic activity of about $64 \% \mathrm{CH}_{4}$ conversion and $79 \% \mathrm{CO}_{2}$ conversion with $\mathrm{H}_{2} / \mathrm{CO} \sim 1$ up to 460 -minute time on stream. At 20wt.\% lanthana loading, it showed rapid loss of surface area, pore-volume, pore diameter, acidity and medium strength basic sites which herald inferior catalytic performance.

\section{Acknowledgments}

The authors would like to express their sincere appreciation to the Deanship of Scientific Research at King Saud University for funding this research project (\# RG-1435-078). RK wants to acknowledge the administration of Sankalchand Patel University for providing research environment. 
[1] M. M. Zain, A. R. Mohamed, An overview on conversion technologies to produce value added products from $\mathrm{CH}_{4}$ and $\mathrm{CO}_{2}$ as major biogas constituents. Renew Sustain Energy Rev 98 (2018) 56-63. https://doi.org/10.1016/j.rser.2018.09.003

[2] Ş.Ö.-Aydınoğlu, E. Özensoy, A. E. Aksoylu, The effect of impregnation strategy on methane dry reforming activity of Ce promoted $\mathrm{Pt} / \mathrm{ZrO}_{2}$, Int. J. Hydrog. Energy 34 (2009) 9711-9722. https://doi.org/10.1016/j.ijhydene.2009.09.005

[3] S. M. S.-Williams, F. B. Noronha, G. Fendley, D. E. Resasco, $\mathrm{CO}_{2}$ Reforming of $\mathrm{CH}_{4}$ over $\mathrm{Pt} / \mathrm{ZrO}_{2}$ Catalysts Promoted with La and Ce Oxides, J. Catal. 194 (2000) 240-249. https://doi.org/10.1006/jcat.2000.2939.

[4] K. Nagaok, M. Okamur, K. Aika, Titania supported ruthenium as a coking-resistant catalyst for high pressure dry reforming of methane, Catalysis Catal. Commun. 2 (2001) 255-260. https://doi.org/10.1016/S1566-7367(01)00043-7.

[5] P. Ferreira-Aparicio, I. Rodríguez-Ramos, J. A Anderson, A. Guerrero-Ruiz, Mechanistic aspects of the dry reforming of methane over ruthenium catalysts, Applied Appl. Catal. A: Gen. 202 (2000) 183-196. https://doi.org/10.1016/S0926-860X(00)00525-1.

[6] L. V. Mattos, E. Rodino, D. E. Resasco, F. B. Passos, F. B. Noronha, Partial oxidation and $\mathrm{CO} 2$ reforming of methane on $\mathrm{Pt} / \mathrm{Al}_{2} \mathrm{O}_{3}, \mathrm{Pt} / \mathrm{ZrO}_{2}$, and $\mathrm{Pt} / \mathrm{Ce}-\mathrm{ZrO}_{2}$ catalysts, Fuel Process. Technol. 83 (2003) 147 - 161. https://doi.org/10.1016/S0378-3820(03)00063-8.

[7] A. M. Efstathiou, A. Kladi, V. A. Tsipouriari, X. E. Verykios, Reforming of Methane with Carbon Dioxide to Synthesis Gas over Supported Rhodium Catalysts: II. A Steady-State Tracing Analysis: Mechanistic Aspects of the Carbon and Oxygen Reaction Pathways to Form CO, Journal J. Catal. 158 (1996) 64-75. https://doi.org/10.1006/jcat.1996.0006.

[8] H. Cheng, G. Li, H. Zhao, X. Lu, Q. Xu, W. Tao, Effects of preparation technique and lanthana doping on $\mathrm{Ni} / \mathrm{La}_{2} \mathrm{O}_{3}-\mathrm{ZrO}_{2}$ catalysts for hydrogen production by $\mathrm{CO}_{2}$ reforming of coke oven gas. Catal. Today 318 (2018) 23-31. https://doi.org/10.1016/j.cattod.2017.11.017

[9] U.-C. Chung, Effect of $\mathrm{H}_{2}$ on Formation Behavior of Carbon Nanotubes. Bull. Korean Chem. Soc., 25 (10) (2004) 1521. https://doi.org/10.4028/www.scientific.net/MSF.475479.3559.

[10] X. U Junke, Z. Wei, W. Jihui, L. I. Zhaojing,M. A Jianxin, Characterization and Analysis of Carbon Deposited during the Dry Reforming of Methane over Ni/La2O3/A12O3 Catalysts, Chin. J. Catal., 30 (11) (2009) 1076-1084. https://doi.org/10.1016/S1872-2067(08)60139-4.

[11] Y. Xu, X.H. Du, J. Li, P. Wang, J. Zhu, F.J. Ge, J. Zhou, M. Song, W. Y. Zhu, A comparison of $\mathrm{Al}_{2} \mathrm{O}_{3}$ and $\mathrm{SiO}_{2}$ supported Ni-based catalysts in their performance for the dry reforming of methane. Ranliao Huaxue Xuebao/Journal Fuel Chem. Technol. 2019, 47, 199208, doi:10.1016/s1872-5813(19)30010-6. 
[12] L. Zhou, L. Li, N. Wei, J. Li, J.-M. Basset, Effect of $\mathrm{NiAl}_{2} \mathrm{O}_{4}$ Formation on Ni/Al $2 \mathrm{O}_{3}$ Stability during Dry Reforming of Methane. ChemCatChem 2015, 7, 2508-2516, doi:10.1002/cctc.201500379

[13] D. Shen, M. Huo, L. Li, S. Lyu, J. Wang, X. Wang, Y. Zhang, J. Li, Effects of alumina morphology on dry reforming of methane over Ni/Al2O3 catalysts. Catal. Sci. Technol. 2020, 10, 510-516, doi:10.1039/c9cy02093d

[14] X. Fang, , C. Peng H. Peng, W. Liu, X. Xu, X. Wang, C. Li, Zhou, W. Methane Dry Reforming over Coke-Resistant Mesoporous Ni-Al ${ }_{2} \mathrm{O}_{3}$ Catalysts Prepared by EvaporationInduced Self-Assembly Method. ChemCatChem 2015, 7, 3753-3762, doi:10.1002/cctc. 201500538

[15] R.L.B.A. Medeiros, G.P. Figueredo, H.P. Macedo, Â. A.S. Oliveira, R.C. Rabelo-Neto, D.M.A. Melo, R.M. Braga, M.A.F. Melo, One-pot microwave-assisted combustion synthesis of Ni-Al2O3 nanocatalysts for hydrogen production via dry reforming of methane. Fuel 2020, 119511, doi:10.1016/j.fuel.2020.119511

[16] Y. Zhao, Y. Kang, H. Li, H. Li, $\mathrm{CO}_{2}$ conversion to synthesis gas: Via DRM on the durable Al2O3/Ni/Al2O3 sandwich catalyst with high activity and stability. Green Chem. 2018, 20, 2781-2787, doi:10.1039/c8gc00743h

[17] Z. Alipour, M. Rezaei, F. Meshkani, Effects of support modifiers on the catalytic performance of $\mathrm{Ni} / \mathrm{Al}_{2} \mathrm{O}_{3}$ catalyst in $\mathrm{CO}_{2}$ reforming of methane. Fuel 2014, 129, 197-203, doi:10.1016/j.fuel.2014.03.045

[18] A.S. Al-Fatesh, M.A. Naeem, A.H. Fakeeha, A.E. Abasaeed, $\mathrm{CO}_{2}$ Reforming of Methane to Produce Syngas over $\gamma-\mathrm{Al}_{2} \mathrm{O}_{3}$-Supported Ni-Sr Catalysts. Bull. Chem. Soc. Jpn. 2013, 86, 742-748, doi:10.1246/bcsj.20130002

[19] A. Fouskas, M. Kollia, A. Kambolis, C. Papadopoulou, H. Matralis, Boron-modified $\mathrm{Ni} / \mathrm{Al}_{2} \mathrm{O}_{3}$ catalysts for reduced carbon deposition during dry reforming of methane. Appl. Catal. A Gen. 2014, 474, 125-134, doi:10.1016/j.apcata.2013.08.016.

[20] S.H. Seok, H.C. Sun, E.D. Park, H.H. Sung, S.L. Jae, Mn-promoted Ni/Al ${ }_{2} \mathrm{O}_{3}$ catalysts for stable carbon dioxide reforming of methane. J. Catal. 2002, 209, 6-15, doi:10.1006/jcat.2002.3627

[21] N. Rahemi, M. Haghighi, A.A. Babaluo, M.F. Jafari, S. Khorram, Non-thermal plasma assisted synthesis and physicochemical characterizations of $\mathrm{Co}$ and $\mathrm{Cu}$ doped $\mathrm{Ni} / \mathrm{Al}_{2} \mathrm{O}_{3}$ nanocatalysts used for dry reforming of methane. Int. J. Hydrogen Energy 2013, 38, 16048-16061, doi:10.1016/j.ijhydene.2013.08.084.

[22] D. Vroulias, N. Gkoulemani, C. Papadopoulou, H. W Matralis, -modified Ni/Al2O3 catalysts for the dry reforming of methane: Effect of W loading. Catal. Today 2020, 355, 704715, doi:10.1016/j.cattod.2019.05.066 
[23] R.Y. Chein, W.Y. Fung, Syngas production via dry reforming of methane over $\mathrm{CeO}_{2}$ modified $\mathrm{Ni} / \mathrm{Al}_{2} \mathrm{O}_{3}$ catalysts. Int. J. Hydrogen Energy 2019, 44, 14303-14315, doi:10.1016/j.ijhydene.2019.01.113

[24] S. Therdthianwong, C. Siangchin, A. Therdthianwong, Improvement of coke resistance of $\mathrm{Ni} / \mathrm{Al}_{2} \mathrm{O}_{3}$ catalyst in $\mathrm{CH}_{4} / \mathrm{CO}_{2}$ reforming by $\mathrm{ZrO}_{2}$ addition. Fuel Process. Technol. 2008, 89, 160-168, doi:10.1016/j.fuproc.2007.09.003

[25] K. Li, C. Pei, X. Li, S. Chen, X. Zhang, R. Liu, J. Gong, Dry reforming of methane over $\mathrm{La}_{2} \mathrm{O}_{2} \mathrm{CO}_{3}$-modified Ni/Al $\mathrm{Al}_{2} \mathrm{O}_{3}$ catalysts with moderate metal support interaction. Appl. Catal. B Environ. 2020, 264, 118448, doi:10.1016/j.apcatb.2019.118448

[26] A. S. Al-Fatesh, R. Kumar, S. O. Kasim, A. A. Ibrahim, A. H. Fakeeha, A. E. Abasaeed, R. Alrasheed, A. Bagabas, M. L. Chaudhary, F. Frusteri, B. Chowdhury, The effect of modifier identity on the performance of Ni-based catalyst supported on $\gamma-\mathrm{Al}_{2} \mathrm{O}_{3}$ in dry reforming of methane, Catal. Today 348 (2020) 236-242. https://doi.org/10.1016/j.cattod.2019.09.003.

[27] A. H. Fakeeha, A. A. Bagabas, M. S. Lanre, Ahmed I. Osman, S. O. Kasim, A. A. Ibrahim, R. Arasheed, A. Alkhalifa, A. Y. Elnour, A. E. Abasaeed and A. S. Al-Fatesh, Catalytic Performance of Metal Oxides Promoted Nickel Catalysts Supported on Mesoporous $\gamma$-Alumina in Dry Reforming of Methane, Processes, 8 (2020) 522. https://doi.org/10.3390/pr8050522.

[28] H. Schaper, E. B. M. Doesburg, L. L. Van Reijen, H. Schaper, E.B.M. Doesburg, L.L. van Reijen, The influence of lanthanum oxide on the thermal stability of gamma alumina catalyst supports, Appl. Catal. 7 (1983) 211-220. https://doi.org/10.1016/0166-9834(83)80009-8.

[29] N. D. Charisiou, L. Tzounis, V. Sebastian, S. J. Hinder, M.A. Baker, K. Polychronopoulou, M. A. Goula, Investigating the correlation between deactivation and the carbon deposited on the surface of $\mathrm{Ni} / \mathrm{Al}_{2} \mathrm{O}_{3}$ and $\mathrm{Ni} / \mathrm{La}_{2} \mathrm{O}_{3}-\mathrm{Al}_{2} \mathrm{O}_{3}$ catalysts during the biogas reforming reaction. Appl. Surf. Sci. 474 (2019) 42-56. https://doi.org/10.1016/j.apsusc.2018.05.177.

[30] R. M. Navarro, M. C. Álvarez-Galván, F. Rosa, J. L. G. Fierro, Hydrogen production by oxidative reforming of hexadecane over $\mathrm{Ni}$ and Pt catalysts supported on Ce/La-doped $\mathrm{Al}_{2} \mathrm{O}_{3}$, Appl. Catal. A: Gen. 297 (2006) 60-72. https://doi.org/10.1016/j.apcata.2005.08.036

[31] W. Mo, F. Ma, Y. Ma, X. Fan, The optimization of $\mathrm{Ni}-\mathrm{Al}_{2} \mathrm{O}_{3}$ catalyst with the addition of $\mathrm{La}_{2} \mathrm{O}_{3}$ for $\mathrm{CO}_{2}-\mathrm{CH}_{4}$ reforming to produce syngas. Int. J. Hydrog. Energy 44 (2019) 2451024524. https://doi.org/10.1016/j.ijhydene.2019.07.204.

[32] K. W. Siew, H. C. Lee, J. Gimbun, S. Y. Chin, M. R. Khan, Y. H. Taufiq-Yap, C. K. Cheng, Syngas production from glycerol-dry $\left(\mathrm{CO}_{2}\right)$ reforming over La-promoted $\mathrm{Ni} / \mathrm{Al}_{2} \mathrm{O}_{3}$ catalyst, Renewable Energy 74 (2015) 441-447. https://doi.org/10.1016/j.renene.2014.08.048.

[33] T. Hou, S. Zhang, Y. Chen, D. Wang, W. Cai, Hydrogen production from ethanol reforming: catalysts and reaction mechanism. Renew Sustain. Energy Rev. 44 (2015) 132-148. https://doi.org/10.1016/j.rser.2014.12.023.

[34] M. Miyamoto, A. Hamajima, Y. Oumi, S. Uemiya, Effect of basicity of metal doped $\mathrm{ZrO}_{2}$ supports on hydrogen production reactions, Int. J. Hydrog. Energy 43 (2018) 730-738. https://doi.org/10.1016/j.ijhydene.2017.11.041. 
[35] H. Chen, H. Yu, F. Peng, H. Wang, J. Yang, M. Pan, Efficient and stable oxidative steam reforming of ethanol for hydrogen production: effect of in situ dispersion of $\mathrm{Ir}$ over $\mathrm{Ir} / \mathrm{La}_{2} \mathrm{O}_{3}$. J. Catal. 269 (2010) 281-290. https://doi.org/10.1016/j.jcat.2009.11.010.

[36] M.-N. N. Shafiqah, H. N. Tran, T. D. Nguyen, P. T. T. Phuong, B. Abdullah, S. S. Lam, P. Nguyen-Tri, R.Kumar, S. Nanda, D.-V. N.Vo, Ethanol $\mathrm{CO}_{2}$ reforming on $\mathrm{La}_{2} \mathrm{O}_{3}$ and $\mathrm{CeO}_{2}-$ promoted $\mathrm{Cu} / \mathrm{Al}_{2} \mathrm{O}_{3}$ catalysts for enhanced hydrogen production, Int. J. Hydrog. Energy 45 (2020) 18398-18410. https://doi.org/10.1016/j.ijhydene.2019.10.024.

[37] S. Isarapakdeetham, P. K.-Lohsoontorn, S. Wongsakulphasatch, W. Kiatkittipong, N. Laosiripojana, J.Gonge, S. Assabumrungrat, Hydrogen production via chemical looping steam reforming of ethanol by Ni-based oxygen carriers supported on $\mathrm{CeO}_{2}$ and $\mathrm{La}_{2} \mathrm{O}_{3}$ promoted $\mathrm{Al}_{2} \mathrm{O}_{3}$, Int. J. Hydrog. Energy $45 \quad$ (2020) 1477-1491. https://doi.org/10.1016/j.ijhydene.2019.11.077.

[38] C. Chen, X. Wang, L. Zhang, X. Zou, W. Ding, X. Lu, Synthesis of mesoporous Ni- $\mathrm{La}_{2} \mathrm{O}_{3}$ $/ \mathrm{SiO}_{2}$ by ploy(ethylene glycol)-assisted sol-gel route as highly efficient catalysts for dry reforming of methane with a $\mathrm{H}_{2} / \mathrm{CO}$ ratio of unity. Catal. Commun. 94 (2017) 38-41. https://doi.org/10.1016/j.catcom.2017.02.018.

[39] J. Zhu, X. Peng, L. Yao, J. Shen, D. Tong, C. Hu, The promoting effect of La, Mg, Co and $\mathrm{Zn}$ on the activity and stability of $\mathrm{Ni} / \mathrm{SiO}_{2}$ catalyst for $\mathrm{CO}_{2}$ reforming of methane, Int. J. Hydrog. Energy 36 (2011) 7094-7104. https://doi.org/10.1016/j.ijhydene.2011.02.133

[40] D. Liu, X.Y. Quek, H.A. Wah, G. Zeng, Y. Li, Y. Yang, Carbon dioxide reforming of methane over nickel-grafted SBA-15 and MCM-41 catalysts, Catal. Today 148 (2009) 243265. https://doi.org/10.1016/j.cattod.2009.08.014

[41] Bartholomew CH. Mechanisms of catalyst deactivation. Appl Catal Gen 2001;212:17e60. https://doi.org/10.1016/S0926- 860X(00)00843-7.

[42] V. Palma,E. Meloni,S. Renda, M. Martino, Catalysts for Methane Steam Reforming Reaction: Evaluation of $\mathrm{CeO} 2$ Addition to Alumina-Based Washcoat Slurry Formulation, J Carbon Research. 6 (2020) 52. https://doi.org/10.3390/c6030052.

[43] A. E. CLuna, M. E. Iriarte, Carbon dioxide reforming of methane over a metal modified $\mathrm{Ni}-\mathrm{Al}_{2} \mathrm{O}_{3}$ catalyst, Applied Appl. Catal. A: Gen. 343 (2008) 10-15. https://doi.org/10.1016/j.apcata.2007.11.041.

[44] F. S. Pettit, E. H. Randklev, E. J. Felten, Formation of $\mathrm{NiAl}_{2} \mathrm{O}_{4}$ by Solid State Reaction, Journal of The American Ceramic Society, 49 (1966) 199-203.

[45] P. Nortier, P. Fourre, A.B. Mohammed Saad, O. Saur and J.C. Lavalley, Appl. Catal., 61 (1990) 141.

[46] C. Dyer, P. J. Hendra, Surface hydration of aqueous $\gamma-\mathrm{Al}_{2} \mathrm{O}_{3}$ studied by Fourier transform Raman and infrared spectroscopy-I. Initial results, Spectrochem Acta. 49A (1993) 691-705. https://doi.org/10.1016/0584-8539(93)80092-O. 
[47] L. Vlaev, D. Damyanov, M. Mohamed, Infrared spectroscopy study of the nature and reactivity of a hydrate coverage on the surface of $\gamma-\mathrm{Al}_{2} \mathrm{O}_{3}$, Colloids Surf. 36 (1989) 427-437. https://doi.org/10.1016/0166-6622(89)80257-4.

[48] N. D. Parkyns, Influence of thermal pretreatment on the infrared spectrum of carbon dioxide adsorbed on alumina, J. Phy. Chem. 76 (1971) 526-531. https://doi.org/10.1021/j100674a014.

[49] G. Busca, V. Lorenzelli, Infrared Spectroscopic Identification of Species Arising from Reactive Adsorption of Carbon Oxides on Metal Oxide Surfaces, Material Chemistry 7 (1982) 89-126.

[50] Pham MH, Goujard V, Tatibouët JM, Batiot-Dupeyrat C. Activation of methane and carbon dioxide in a dielectric-barrier discharge-plasma reactor to produce hydrocarbonsInfluence of $\mathrm{La}_{2} \mathrm{O}_{3} / \gamma-\mathrm{Al}_{2} \mathrm{O}_{3}$ catalyst. Catal. Today 171 (2011) 67-71. https://doi.org/10.1016/j.cattod.2011.03.015.

[51] Barrera A, Fuentes S, Viniegra M, Avalos-Borja M, Bogdanchikova N, Campa-Molina J. Structural properties of $\mathrm{Al}_{2} \mathrm{O}_{3}-\mathrm{La}_{2} \mathrm{O}_{3}$ binary oxides prepared by sol-gel. Mater. Res. Bull. 42 (2007) 640-8. https://doi.org/10.1016/j.materresbull.2006.08.001.

[52] D. Salinasa, N. Escalonab, G. Pecchie, J. L. G. Fierro, Lanthanum oxide behavior in $\mathrm{La}_{2} \mathrm{O}_{3}-\mathrm{Al}_{2} \mathrm{O}_{3}$ and $\mathrm{La}_{2} \mathrm{O}_{3}-\mathrm{ZrO}_{2}$ catalysts with application in FAME production, Fuel 253 (2019) 400-408. https://doi.org/10.1016/j.fuel.2019.05.015.

[53] L. Vlaev, D. Damyanov, M. Mohamed, Infrared Spectroscopy Study of the Nature and Reactivity of a Hydrate Coverage on the Surface of $\gamma$-A $1_{2} 0_{3}$, Colloids Surf., 36 (1989) 427 437. https://doi.org/10.1016/0166-6622(89)80257-4.

[54] J. Baltrusaitis, J. H. Jensen, V. H. Grassian, FTIR Spectroscopy Combined with Isotope Labeling and Quantum Chemical Calculations to Investigate Adsorbed Bicarbonate Formation Following Reaction of Carbon Dioxide with Surface Hydroxyl Groups on $\mathrm{Fe}_{2} \mathrm{O}_{3}$ and $\mathrm{Al}_{2} \mathrm{O}_{3}, \mathrm{~J}$. Phys. Chem. B , 110 (2006)12005-12016. https://doi.org/10.1021/jp057437j.

[55] Y. Pan, C.-J. Liu, Q. Ge, Adsorption and Protonation of $\mathrm{CO}_{2}$ on Partially Hydroxylated $\gamma$ $\mathrm{Al}_{2} \mathrm{O}_{3}$ Surfaces: A Density Functional Theory Study, Langmuir 24 (2008)12410-12419. https://doi.org/10.1021/la802295x.

[56] D. Salinas, C. Sepúlveda, N. Escalona, J. L. G. Fierro, G. Pecchia, Sol-gel $\mathrm{La}_{2} \mathrm{O}_{3}-\mathrm{ZrO}_{2}$ mixed oxide catalysts for biodiesel production, J. Energy Chem. 27 (2018) 565-572. https://doi.org/10.1016/j.jechem.2017.11.003.

[57] Sandip Mandal, Chiranjit Santra, Rawesh Kumar, Malay Pramanik, Sumbul Rahman, Asim Bhaumik, Sudip Maity, Debasis Sen and Biswajit Chowdhury, Niobium doped hexagonal mesoporous silica (HMS-X) catalyst for vapor phase Beckmann rearrangement reaction, RSC Adv., 4 (2014) 845-854. https://doi.org/10.1039/C3RA41840E.

[58] S. Rahman, C. Santra, R. Kumar, J. Bahadur, A. Sultana, R. Schweins, D. Sen, S. Maity, S. Mazumdar, Biswajit Chowdhury, Highly active Ga promoted Co-HMS-X catalyst towards styrene epoxidation reaction using molecular $\mathrm{O}_{2}$, Appl. Catal. A: Gen. 482 (2014) 61-68. https://doi.org/10.1016/j.apcata.2014.05.024. 
[59] M. Toyoda, Y. Nanbu, Y. Nakazawa, M. Hirano, M. Inagaki, Effect of crystallinity of anatase on photoactivity for methyleneblue decomposition in water, Applied Catalysis B: Environmental 49 (2004) 227-232. https://doi.org/10.1016/j.apcatb.2003.12.012

[60] Z. Y. Hou, O. Yokota, T. Tanaka, T. Yashima. Characterization of Ca-promoted Ni/ $\alpha-$ $\mathrm{Al}_{2} \mathrm{O}_{3}$ catalyst for $\mathrm{CH} 4$ reforming with $\mathrm{CO}_{2}$, Appl. Catal. A, 253 (2003) 381. https://doi.org/10.1016/S0926-860X(03)00543-X.

[61] X. Chen, K. Honda, Z. G. Zhang, $\mathrm{CO}_{2}-\mathrm{CH}_{4}$ reforming over $\mathrm{NiO} / \gamma-\mathrm{Al}_{2} \mathrm{O}_{3}$ in fixedbed/fluidized-bed switching mode, Catal. Today, 93-95 (2004) 87. https://doi.org/10.1016/j.cattod.2004.06.015.

[62] B. S. Liu, C. T. Au, Carbon deposition and catalyst stability over $\mathrm{La}_{2} \mathrm{NiO}_{4} / \gamma-\mathrm{Al}_{2} \mathrm{O}_{3}$ during $\mathrm{CO}_{2}$ reforming of methane to syngas, Appl. Catal A, 244 (2003) 181. https://doi.org/10.1016/S0926-860X(02)00591-4.

[63] D. Salinas, N. Escalona, G. Pecchi, J. L. G. Fierro, Lanthanum oxide behavior in $\mathrm{La}_{2} \mathrm{O}_{3}-$ $\mathrm{Al}_{2} \mathrm{O}_{3}$ and $\mathrm{La}_{2} \mathrm{O}_{3}-\mathrm{ZrO}_{2}$ catalysts with application in FAME production Fuel 253 (2019) 400408. https://doi.org/10.1016/j.fuel.2019.05.015.

[ 64 ] Di Serio M, Ledda M, Cozzolino M, Minutillo G, Tesser R, Santacesaria E. Transesterification of soybean oil to biodiesel by using heterogeneous basic catalysts. Ind. Eng. Chem. Re.s 45(9) (2006) 3009-3014. https://doi.org/10.1021/ie051402o.

[65] Santório R, Veloso CdO, Henriques CA. Preparation, basic properties and catalytic activity of $\mathrm{Mg} / \mathrm{La}$ and $\mathrm{Al} / \mathrm{La}$ catalysts for biodiesel production from refined and acid soybean oil. J. Mol. Catal. A Chem 422 (2016) 234-47. https://doi.org/10.1016/j.molcata.2015.12.006.

[66] Y. Vafaeian, M. Haghighi, S. Aghamohammadi, Ultrasound assisted dispersion of different amount of Ni over ZSM-5 used as nanostructured catalyst for hydrogen production via $\mathrm{CO}_{2}$ reforming of methane, Energy Convers. Manag. 76 (2013) 1093-1103. https://doi.org/10.1016/j.enconman.2013.08.010.

[67] F. Mirzaei, M. Rezaei, F. Meshkani, Coprecipitated Ni-Co bimetallic nanocatalysts for methane dry reforming, Chem. Eng. Technol. 37 (2014) 973-978. https://doi.org/10.1002/ceat.201300729.

[68] S. Das, M. Sengupta, J. Patel, A. Bordoloi, A study of the synergy between support surface properties and catalyst deactivation for $\mathrm{CO}_{2}$ reforming over supported Ni nanoparticles, Appl. Catal., A 545 (2017) 113-126. https://doi.org/10.1016/j.apcata.2017.07.044.

[69] N. Wang, W. Chu, T. Zhang, X. S. Zhao, Synthesis, characterization and catalytic performances of Ce-SBA-15 supported nickel catalysts for methane dry reforming to hydrogen and syngas, Int. J. Hydrog. Energy $37 \quad$ (2012) 19-30. https://doi.org/10.1016/j.ijhydene.2011.03.138.

[70] J. Ashok, S. Naveen Kumar, A. Venugopal, V. Durga Kumari, M. Subrahmanyam, COXfree $\mathrm{H}_{2}$ production via catalytic decomposition of $\mathrm{CH}_{4}$ over Ni supported on zeolite catalysts, J. Power Sources 164 (2007) 809-814. https://doi.org/10.1016/j.jpowsour.2006.11.029. 
